\title{
South Korean Media Representation of Yemeni Refugees
}

\author{
RAITH ZEHER ABID \\ English Department, College of Education for Human Sciences, Kerbala University, \\ Freaha, Kerbala, Iraq \\ raithzeher@gmail.com
}

Published online: 15 April 2020

To cite this article: Raith Zeher Abid. 2020. South Korean media representation of Yemeni refugees. KEMANUSIAAN the Asian Journal of Humanities 27(1): 89-114. https://doi.org/10.21315/ kajh2020.27.1.5

To link to this article: https://doi.org/10.21315/kajh2020.27.1.5

\begin{abstract}
This research examines how a handful of Yemeni refugees who arrived in South Korea are depicted in the online media news reports of the country. A total of 73 articles were collected from five different Korean English news outlets. The representation of social actor theory and conceptual metaphor theory were used in the analysis of the data. The outcomes of the analysis indicate that these Yemeni refugees are undesirably represented by the South Korean media. The continuance of such undesirable representation of these groups by the media, which is well-known for its influence on the public's frame of thought, endangers their existence. It is hoped that the multi-layered analysis of discourse that this research offers will provide awareness to readers about the way blameless Yemenis are negatively rendered in the online media news reports of South Korea.
\end{abstract}

Keywords and phrases: Critical Discourse Analysis, Yemeni refugees, South Korean media, social actor theory, metaphors

\section{Introduction}

Media outlets in society are prominent because its authority, according to Talbot (2007), is as influential as other major establishments, including the church. Media discourse is a fundamental resource of influence that can be used by the powerful to mould the frame of thought of the public to suit their needs. This idea was emphasised by Tator, Henry and Mattis $(1998,31)$ who stated that media are resources of "beliefs and values" that have the power to frame the overall perception of the public. When it comes to minority groups, media are typically used by the powerful in society to "generate images that reinforce cultural racism" by creating a gap between "us", the majority group and "them", the minority group (Tator, Henry and Mattis 1998, 32). However, the recent technological advances 
allow all people to share resources throughout the world via the use of internet. This type of media is called new media, whereby people can use blogs or social media websites to publish stories, pictures and videos of events by using their mobile phones, laptops or tablets. This type of reportage "will not substitute professional journalism, but can correct it and support it" as well as "filling the gaps left behind" (Santoro 2012, 16). Therefore, the infrastructure of traditional media in general is deemed to be influenced by these technological advances. Hence, according to Papathanassopoulos (2011) and Santoro (2012), the recent developments in technology created a paradigm shift in the way media report its news. This transformation might have an effective influence on the manner media represent minority groups, specifically refugees.

Throughout history, wars force people to flee from the carnage in their country. These people are perceived as refugees. A refugee, according to the United Nations High Commissioner for Refugees (UNHCR) (2013), is "someone who has been forced to flee his or her country because of persecution, war or violence" as well as because of a "well-founded fear of persecution for reasons of race, religion, nationality, political opinion or membership in a particular social group".

One of the less known exoduses of refugees is the mass departure of Yemenis from their motherland to South Korea. Since there are no studies that examined the depiction of Yemeni refugees in South Korea, the author hypothesises that because of the small number of Yemeni refugees, 550 Yemenis compared to 51,000,000 Korean citizens, the representation of this minority group in the South Korean media will be sympathetic and positive contrary to the general conclusions arrived at by previous studies. This hypothesis is based on the idea that tension between host communities and refugees generally arises when the number of refugees is substantial, as in Syrian refugees in Lebanon (Abid, Manan and Amir, 2017). Therefore, the author will examine whether Yemenis are represented positively or negatively in the English Media outlets of South Korea using the social actor theory of Van Leeuwen (2008) and conceptual metaphor theory of Lakoff and Johnson (2003).

\section{Studies on Refugees and Minority Groups}

One of the fundamental objectives of Critical Discourse Analysis (CDA) is to examine how the "self" and the "other" are rendered in discourse. Consequently, minority groups are of interest to CDA analysts who endeavour to examine how these groups are depicted by the discourse of the majority group and to make discourse consumers conscious of the various techniques used by the discourse makers to discriminate these minority groups. Rojo and Van Dijk (1997) investigated the 
Spanish Secretary of Interior, Mayor Oreja, speech about the eviction of a group of African "illegal" migrants from Melilla. The study showed that migrants are nonexistent as a group of people in Spain and its general discourse, thus highlighting the presence of ethnic inequality and racism. Rasinger (2010), who examined the representation of migrants and minority groups in the United Kingdom, arrived at the same results which indicated that minorities were unfairly represented in a negative manner by media discourse. This negative depiction was related to the rising level of crimes that were linked to these minority groups. Additionally, migrants and minority groups were presented in news discourse as individuals from whom the "natives" need protection. The depiction of minority groups in the British newspapers was examined by KhosraviNik (2009). The results of his study showed that the analysed social actors were predominantly depicted negatively in the corpus by describing them as a threat and liability via using water mass metaphors and natural disasters metaphors. Similar results were arrived at by Gabrielatos and Baker (2008) who investigated the construction of refugees and asylum seekers in the British media during the period of 1996-2005. The results of the study indicated that refugees were negatively depicted using water mass metaphors.

Teo (2000) studied the depiction of Vietnamese immigrants in two Australian newspapers. The results showed that there was a gap between the "self" and the "other" in which Vietnamese immigrants were relegated by the white majority. Baker et al. (2008) reached the same results which indicated that articles in the research corpus (Refugees Asylum Seekers Immigrants and Migrants [RASIM]) commonly used negative depictions of refugees to discriminate between the ingroups (British citizens) and the out-groups (refugees). These results are compatible with Cartner (2009) who stated that the Australian newspapers investigated in his study supported "efforts to marginalize the refugee other based on the threat to Australian culture they allegedly posed" (Cartner 2009, 99). Compatible results were also found by Hanson-Easey and Augoustinos (2010) who investigated the way Sudanese refugees were depicted in the interactions between Minister Andrews and important figures in the refugees' intake of Australia. The results of the study indicated that Sudanese refugees were represented as uneducated and dangerous. Furthermore, the corpus analysis showed that prejudice discourse existed by employing a genre of "racism that goes on doing the same old work justifying and legitimizing exclusion and the marginalization of minorities and 'those not like Us"' (Hanson-Easey and Augoustinos 2010, 319). Abid, Manan and Amir (2017) examined the metaphors used in the depiction of Syrian refugees. The results indicated that Syrian refugees were depicted as an inanimate subject that negatively influences host communities. 


\section{Analytical Framework}

\section{Van Leeuwen (2008)}

Discourses to this approach characterise "what is going on, they also evaluate it, ascribe purposes to it, justify it and so on" (Van Leeuwen 2008, 6). Such features of depiction are fundamental as they can be much more prominent than the social practice itself. The crucial premise of Van Leeuwen's theory is to examine the way social actors are represented in the English language. Instead of focusing on examining the linguistic categories (such as transitivity) and the linguistic operations (as in nominalisation), Van Leeuwen focuses the analysis on exploring the "sociosemantic inventory of the ways in which social actors can be represented and establish the sociological and critical relevance" to the different categories which will then be explored linguistically in a text (Van Leeuwen 2008, 23). These categories, which Van Leeuwen (2008) proposed to be the focus of CDA analysts, should be perceived as pan-semiotic whereby a culture or a context within a culture does not only have its own "specific array of ways of representing the social world, but also its own specific ways of mapping the different semiotic modes onto this array, or prescribing, with greater or lesser strictness, what can be realized verbally and visually" (Van Leeuwen 2008, 25).

The several rhetorical and linguistic layers of analysis in this theory are unified by the concept of "social actor" in preference to linguistic concepts (Van Leeuwen 2008). Hence, the theory emphasises the sociological categories of discourse, as in role allocation (the active or passive roles ascribed to social actors in discourse) rather than the linguistic categories, such as transitivity (verbs that can take direct objects).

Social actors are variously represented within the linguistic structures of discourse. Hence, Van Leeuwen's theory offers several diverse sociological categories that can be used to analyse the depiction of social actors. These categories (as shown in Table 1) will be utilised in the analysis of this study's corpus.

\section{Lakoff and Johnson (2003)}

Although literary metaphors are sometimes conceived similarly to everyday metaphors, they are a special type of metaphors because writers utilise diverse processes, such as extending, elaborating, questioning and combining, to distinguish them from everyday metaphors (Kövecses 2010, 59). Furthermore, while literary metaphors are consciously formulated by the poet or the writer to achieve a 
predetermined artistic impression, everyday metaphors are unconsciously utilised in everyday discourse whereby the source and the target domains are interconnected to refer to a certain phenomenon. Lakoff and Johnson $(2003,257)$ emphasised this notion via stating that the "mechanism of metaphor is largely unconscious", thus, "we will think and speak metaphorically, whether we know it or not".

Table 1. Linguistic categories of the representation of social actors in discourse

\begin{tabular}{|c|c|c|}
\hline $\begin{array}{l}\text { Sociological categories } \\
\text { of discourse }\end{array}$ & Type & Linguistic description \\
\hline \multirow[t]{2}{*}{ 1. Role allocation } & Activation & $\begin{array}{l}\text { (a) The social actor in a subject position } \\
\text { (b) Circumstantialisation (by and from are } \\
\text { used to signify the agent) } \\
\text { (c) Premodification of nominalisations } \\
\text { (d) Postmodification of nominalisations }\end{array}$ \\
\hline & Passivation & $\begin{array}{l}\text { (a) Subjection } \\
\text { (b) Beneficialisation }\end{array}$ \\
\hline \multirow[t]{2}{*}{$\begin{array}{l}\text { 2. Genericisation and } \\
\text { specification }\end{array}$} & Generic reference & $\begin{array}{l}\text { (a) Plural nouns without articles } \\
\text { (b) Singular nouns with definite articles }\end{array}$ \\
\hline & Specific reference & Specific noun \\
\hline 3. Assimilation & Aggregation & $\begin{array}{l}\text { (a) Indefinite quantifiers } \\
\text { (b) Definite quantifiers }\end{array}$ \\
\hline 4. Indetermination & Indetermination & Exophoric references \\
\hline 5. Identification & Identification & $\begin{array}{l}\text { (a) Classifying social actors in terms of age, } \\
\text { race, religion, class and so on. } \\
\text { (b) Identifying social actors in terms of their } \\
\text { kinship and work relations. } \\
\text { (c) Identifying social actors in terms of } \\
\text { bodily characteristics that include hair } \\
\text { colour, eye colour, height and so on. }\end{array}$ \\
\hline
\end{tabular}

Conceptual domains are important in the analysis of metaphors as they provide an in-depth view of the conceptual representation that the public has about events or people. Consequently, metaphors are defined as the realisation of "one conceptual domain in terms of another conceptual domain" (Kövecses 2010, 4). These domains are called the source and target domains. While target domain may include love, arguments, life, theory, social organisations, ideas and so on, source domain can include war, journeys, buildings, plants, food, etc. Therefore, everyday language metaphors such as "love is a journey", "time is money", "theories are buildings" and so on, are created from combining the source and target domains. 
Metaphors are fundamental in this research because besides being common in media discourse, they can be used as a source of manipulation (Lakoff 1991). According to Lakoff (1991), in the first Gulf War, Bush endeavoured to rally the American public into war against Iraq by rendering the assault crucial in saving the oil-life line which is important to the American economy. The public, however, was against the war. Subsequently, the Bush administration changed the strategy by portraying Saddam Hussein as "Hitler" whose army is "raping" Kuwait and that America's role is to "protect freedom, protect our future and protect the innocent" and to "push Saddam Hussein back" (Lakoff 1991). This is deemed to be one of the factors that motivated the American public to support the war on Iraq. This manipulation succeeded because people rationalise the world in terms of frames and metaphors which are crucial in cognitive science. The importance of metaphors in manipulating the public's frame of thought was noted by Lakoff (2004, 73) via stating:

It is a common folk theory of progressives that "The facts will set you free!" If only you can get all the facts out there in the public eye, then every rational person will reach the right conclusion. It is a vain hope. Human brains just don't work that way. Framing matters. Frames once entrenched are hard to dispel.

\section{Data and Methodology}

This research aims at examining the way Yemeni refugees who reside in South Korea are represented in the online media news reports of the country. Therefore, Van Leeuwen's (2008) social actor theory and Lakoff and Johnson's (2003) conceptual metaphor theory will be utilised to analyse the collected news reports. The news reports were collected from five different online media outlets: The JoongAng Ilbo, YonHap News, The Korea Times, The Chosun Ilbo and Korea Herald. The selection of these media outlets was based on two criteria: (1) the medium of communication is English and (2) they must have an archival system that has a representative database. A total of 73 articles were collected. The website addresses (URLs) of the selected articles were collected into a text file which was fed into the BootCat program (Baroni and Bernardini 2004). Then, the articles were downloaded by the program into text files that were printed and analysed by the author. It is important to note that the collected articles were analysed separately by the author of this article and an interrater. The results were then compared to ensure reliability and objectivity. Sources of each article are listed in the Appendix section at the end of this article. 


\section{Results and Discussion}

The collected news reports refer to Yemeni refugees in South Korea as refugees (51\%), asylum seekers (29\%) and Yemenis (20\%). The author believes that the implementation of the expression Yemenis is intended to strip them from any benefits and sympathetic dispositions that are associated with the expression refugees. Therefore, when the Yemenis are deemed to be stealing jobs or endangering the fabric of the society, the journalist is backgrounding the facts that these Yemenis are refugees who have fled persecution and a bloody civil war in their country.

\section{Results from Van Leeuwen's (2008) social actor theory}

\section{Role allocation}

In this study, the category of role allocation analyses the instances in which social actors represent an active dynamic force or passive in relation to an action as depicted in discourse. The grammatical manifestation of role allocation in this corpus is predominantly represented by social actors in the subject position and postmodification of nominalisation. The following chart (as shown in Figure 1) depicts the percentages of the passive and active rendering of refugees in the news reports.

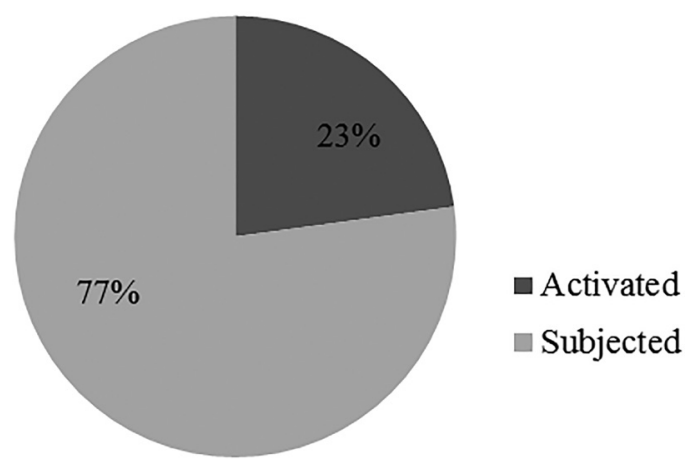

Figure 1. Role allocation

The chart clearly shows that Yemeni refugees are more in the passive position than active position. To examine the diverse topics that are associated with the active and passive roles of Yemeni refugees in the news reports, the author collected all the instances in which Yemeni refugees are mentioned and grouped them into topics based on the context of their occurrence. The overall results of this analysis are represented in Table 2. 
Table 2. The topics of activation and passivation in the collected news reports

\begin{tabular}{llc}
\hline Role allocation & Topics & Frequency (\%) \\
\hline Activation & Movement & 35 \\
& Refugees' challenges & 21 \\
& Official procedures & 18 \\
& Ramification of hosting refugees & 16 \\
& Employment & 10 \\
\hline Subjection & Censuring refugees & 56 \\
& Aiding refugees & 44 \\
\hline
\end{tabular}

Yemeni refugees in the collected news reports are represented as active social actors in terms of their movement. This category is mainly initiated when mentioning their entrance to South Korea, as in "more than 500 Yemenis have arrived on Jeju Island this year", "39 Yemeni asylum seekers arrived and their numbers grew to 92 in 2016" and "over 500 Yemeni refugees arrived on Jeju Island recently", how they entered South Korea, as in "the Yemenis normally flew on a direct flight from Malaysia" and "the asylum seekers who have chosen Jeju can be traced to a direct flight from Kuala Lumpur" and how they exploit the 30-day visa free programme to enter Jeju island, as in "more than 500 Yemeni asylum seekers arrived in Jeju under a no-visa program" and "the Yemenis have entered Korea on the island's visa-free program".

The challenges that the refugees face is the second most frequent topic used in the activation category. This topic depicts the lack of resources that the Yemeni refugees suffer from, as in "some Yemenis come to us saying they are about to go broke", "some Yemenis in Jeju have resorted to sleeping outside", "most refugees arrived with little money to live there for about a month", the need for medical care, as in "32 of the refugees were still in need of medical support" and "Yemeni asylum seekers on South Korea's Jeju Island are in need of medical attention" and the lack of freedom, as in "more than 500 Yemeni refugees are stuck on Jeju Island" and "the Yemenis are currently 'stranded' in Jeju".

The topic of official procedures mainly deals with the South Korean's government process of granting a refugee status for Yemenis, as in "a total of 552 Yemenis registered for refugee recognition in Korea", "Yemeni refugees are waiting for human rights consultations at the Jeju Migrant Center" and "Yemeni asylum seekers wait for their chance to explain their case to human rights officials". 
The fourth most frequent topic in which social actors are activated signifies the troubles that are triggered by the Yemeni refugees in South Korea. This category mainly depicts the potential criminality of refugees, as in "the Yemenis are terrorists in the guise of refugees", "the refugees are dangerous and should not be accommodated" and "Yemeni asylum seekers are men". The final example is important because the fear of only men refugees is highlighted when discussing the potential sexual crimes that might happen in South Korea. This makes sense because the most significant number of oppositions to Yemeni refugees in Korea comes from female South Koreans (Park 2018). Furthermore, this category of refugees depicts the division in the South Korean society that is caused by the presence of refugees as there are people who want to welcome refugees while others think otherwise, as in "Yemeni asylum seekers in Jeju have become a controversial issue in South Korea" and "Yemeni refugees has divided the island".

There are few instances in the activation category that depicts refugees finding occupation while being hosted in Jeju Island, as in "some Yemeni asylum seekers on Jeju Island have also begun working for used-car dealerships", "the refugees are receiving jobs in industries that do not heavily employ locals", seeking jobs, as in "a group of Yemenis attend a job consulting session on Jeju Island" and "Yemeni refugees line up to receive employment assistance at the Jeju Immigration Office", threatening the job security of South Koreans, as in "Yemenis would steal jobs previously held by Koreans" and "Yemenis came to Korea for financial reasons". This category will be further accentuated when representing refugees as passive social actors in news reports.

The most frequent topic in the analysis of passivation is the censuring of Yemeni refugees. This is mostly represented by associating Yemeni refugees to terrorism, as in "Koreans are in danger of terrorism because of the Yemenis", "some radicals paint the Yemenis as terrorists in the guise of refugees", "rumours about refugees and Muslims also raised fear among the public" and "some opponents spread 'Islamophobia' and allege the Yemenis are terrorists". Economic fear from refugees is mostly represented by the burden of hosting refugees and the financial intention of the Yemenis who entered South Korea, as in "some believe the Yemenis arrived solely for economic advantages", "it takes too much money to house, educate and feed the refugees" and "some are worried Yemenis would steal jobs". The fear that the refugees will devastate South Korea with crimes, as in "some see the influx of refugees as a security threat", "those who oppose (refugees) say they want safety", "allowing Yemeni refugees will inevitably lead to rise in sex crimes", "younger women in particular expressed the most concern about refugees", "online users also expressed concerns of a rise in sexual or child-related crimes, viewing Yemenis as potential criminals or terrorists". This debate is often accentuated by 
providing examples of how Europe is devastated by the existence of refugees, as in "the romantic streets of Paris fade away thanks to refugees", "we've seen and heard a lot about social problems that occurred in Europe after they took refugees" and "another notable case was mass sexual assaults against dozens of women by Muslim refugees from North Africa in Cologne, Germany". Yemenis are also accredited for dividing a homogenous country as there are people who oppose Yemeni refugees while there are others who support them. This is represented throughout the collected news reports, as in "a homogenous country divided over how to handle over 500 Yemenis", "South Koreans are divided on the issue of refugees" and "the nation is divided over the Yemeni refugees". Furthermore, even religious intuitions are at difference because of Yemeni refugees, as in "Korean churches divided over Yemeni refugees" and "a Protestant church pastor expressed worries about the Yemeni refugees".

The second most frequent category in which Yemeni refugees are passivised represents the aid they receive, as in "the Ministry of Justice, in charge of refugee policies, will seek for refugees to settle and find jobs here", "Human Rights Commission of Korea lifted a restriction preventing refugees from getting a job", "the local government has been helping the asylum seekers", "local government plans to provide emergency medical relief for the Yemenis" and "the local government would provide humanitarian assistance to the Yemenis". There are also several instances in which the view that Yemeni refugees are not fake refugees. This is a slogan used throughout the demonstrations that oppose Yemeni refugees, as in "there are no fake refugees". According to Ghani (2018), the term "fake refugees" appeared in South Korea to describe Yemenis because "they were mostly male, were wearing proper clothes and had smartphones".

\section{Generic reference}

As indicated further in this research, a generic reference generalises the social actors into a class of individuals while specific reference classifies the social actor exclusively. Van Leeuwen $(2008,36)$ specified that the tactic of genericisation is intended to figuratively remove social actors from "the readers' world of immediate experience, treated as distant 'others' rather than as people with whom 'we' have to deal in our everyday lives". Generic references in this research are signified by nouns with and without definite article while specific references are signified by proper nouns. In the collected news reports, generic references without determiners are implemented $81 \%$ while generic references with determiners are implemented $19 \%$. It is crucial to note that the categories of genericisation are like that of role allocation and, thus, it is redundant to list the same examples of activation and passivation. 
In the collected 73 news reports, only three times the reporter specified the social actor. Specification is applied to provide Yemeni refugees voice as well as represent them sympathetically so that they can be recognised as individuals with whom the reader can connect. This observation is further emphasised in the prevailing use of refugees' narration of the difficulties they are facing or have already faced in either their country or their host country. For example:

Muneer Almammari, also a former journalist who arrived in Jeju on May 5 , said they were grateful for how Korea had legally allowed them to stay and for the people who willingly helped them.

"Before I came here from Malaysia, I was informed that I would need money to spend for two to three weeks in Jeju until I receive the visa to go to Seoul," Mohammed Alghaodari, 34, told The Korea Herald.

\section{Assimilation}

Assimilation refers examines whether social actors are depicted as individuals or groups. This research focused on two aspects of this category: aggregation and collectivisation. Aggregation enumerates social actors and describes them as statistics, while collectivisation does not. Throughout the corpus of this research, there are several instances whereby Yemeni refugees are preceded by definite quantifiers that are manifested through cardinal numbers as in "Hane and Almammari are among the 561 Yemeni asylum seekers", "the recent arrival on Jeju Island of 549 Yemenis fleeing civil war and hunger" and "a total of 561 Yemenis arrived on Jeju Island this year". There are also several examples whereby Yemeni refugees are represented using indefinite quantifiers, as in "many Yemeni asylum seekers have registered for refugee", "there are around 800 refugees, but the number is probably much bigger", "most Yemenis arrive via direct flights from Malaysia" and "most refugees arrived with little money to live there". Indefinite quantifiers can also be represented by numeratives that represent the head of nominal groups which is signified through using the word "number" as in "the number of Yemenis on Jeju swelled by the hundreds", "the number of asylum seekers from Yemen on Jeju grew" and "the number rose more than ten-fold over the past half year". This strategic form of aggregation, according to Van Leeuwen (2008, 38), does not only deem Yemeni refugees as subjects of "'rational' economic calculation, but also makes them that large horde" that are straining the host countries. The negative function of aggregation is further highlighted by KhosraviNik $(2009,13)$ who stated that aggregation is implemented in discourse to represent a " "thing' whose identity and human features are strategically backgrounded by using numerals instead of proper nouns". 


\section{Collectivisation}

The use of collectivisation in the corpus further accentuates the negative depiction of Yemeni refugees. Yemeni refugees are collectivised via the use of nominals such as newcomers in "wanting the government to toughen refugee laws and reject the newcomers", burden in "I believe Jeju shouldn't bear the burden all alone" and arrivals as in "that similar arrivals could follow and their presence could lead to increases in crime". These instances of negative collectivisations are commonly modified via using adjectives to depict enormity or character such as many, countless, hundreds, huge, immense and overwhelming.

\section{Indetermination}

The category of indetermination in the collected news reports depicts social actors as anonymous entities. This research will only focus on the exophoric reference of "they". There are 70 exophoric instances that depict Yemeni refugees. The majority of the exophoric references used in the news reports represents the way Yemeni refugees took advantage of the South Korean legal system to stay in the country. This is represented since their arrival, as in "they came to Korea aboard a direct flight from Malaysia" and "they flocked to the visa-free island after direct airline services", how the Yemeni refugees took advantage of the visa waiver system in Jeju Island, as in "they can stay for up to 90 days without a visa" and "they came here via a visa waiver program" and how they can stay in the country for more than the legal 90 days by applying for asylum, "they can stay for up to five years while their case is being assessed" and "they are entitled to remain in the country during the court's deliberation". In the reports, there are also several instances that depict the negative presence of Yemeni refugees in the country, as in "they came to Korea to make money", "they will take our jobs", "they only came here for jobs", "they are economic opportunists", "they are potential sexual criminals or terrorists" and "they are Muslims". The notion of being Muslims represents a threat to the South Korean societal fabric as there is fear that they might not assimilate to the major religions of the country (Buddhism, Confucianism and Catholicism) as well as because the overly negative perception of Muslims as terrorists and misogynistic. This is highlighted in statements like "they may pose security threats" and "they do not treat women as humans but mere baby-making machines". Such implementation of the exophoric reference of "they" emphasises an important journalistic purpose of this linguistic device which is to endow "social actors with a kind of impersonal authority, a sense of unseen, yet powerfully felt coercive force" (Van Leeuwen 2008, 40). 
It is a crucial note that in the news reports, the exophoric reference "they" is used to sympathetically depict Yemeni refugees as individuals who escaped their war torn country, as in "they were indeed forced to flee their country because of persecution" and "they wanted to avoid getting conscripted in their war-torn countries" and how they are struggling with minimal resources in the country, as in "they ran out of money to pay for a hotel", "they move out to the streets and become homeless", emphasising their humanity, as in "they are all humans, before anything else" and "they fled in search of hope and a better life", as well as how the Yemenis are helping the economy of Jeju Island, as in "they work either as car dealers or sell second-hand parts scavenged at junkyards" and "they could help Jeju ease serious labour shortages in agriculture", which explains why "farmers are sympathetic about granting refugee status to the asylum seekers".

\section{Identification}

The category of identification in the collected news reports is mainly concerned with religion and gender. Throughout the data, the religion of Yemenis, Islam, is mainly associated with negative representations that create fear and disagreement, as in "other Koreans upset about the Muslims and wanting the government to toughen refugee laws", "they are Muslims", "a common argument goes that Muslim refugees will not assimilate into the larger mainstream society" and "rumours about refugees and Muslims also raised fear among the public". The overly negative representation of Islam is observed by several researchers, the most recent are Törnberg and Törnberg $(2016,132)$ who examined the depiction of Muslim in social media and stated that "Muslims are portrayed in the forum as a homogeneous outgroup that is embroiled in conflict, violence and extremism: characteristics that are described as emanating from Islam as a religion". The use of gender mainly emphasises that Yemenis are men, as in "a Korean man claimed that Muslim men only see women as the "subject of rape and murder", "some raised issues over possible repercussions that a large influx of mostly-male foreigners from a different cultural background may have on the Korean society" and "he (a South Korean) claimed that by allowing male refugees from Yemen, many of whom are single, to stay on Jeju, the Korean government is 'putting Korea's young women in danger'". Virtually every time the notion of Yemenis' gender is raised, the fear that they will incite sexual crimes against South Korean women persists. This notion tends to be accentuated with the idea that Yemenis are Muslim, thus generalising all Muslims as misogynistic individuals who disregard and threaten women. 


\section{Results from Lakoff and Johnson's (2003) conceptual metaphor theory}

Conceptual metaphors, as indicated above, are perceived as the perception of one conceptual domain in terms of another conceptual domain via carrying out systematic mappings between the two domains (Lakoff and Johnson 2003). Metaphors are realised as devices that are "pervasive in everyday life, not just in language but in thought and action" because even "our ordinary conceptual system, in terms of which we both think and act, is fundamentally metaphorical in nature" (Lakoff and Johnson 2003, 3). Several metaphors were used in relation to Yemeni refugees throughout the corpus. The water metaphor is the main type used to signify the enormous number of Yemeni refugees who have entered South Korea.

The most frequent (54\%) metaphor used in representing Yemeni refugees is the metaphor of influx, as in "unprecedented influx of Yemeni asylum seekers in Jeju sparks public discussion", "Jeju Island saw an influx of asylum seekers from Yemen" and "the unprecedented influx of Yemeni asylum seekers in Jeju has become a controversial issue". The rest of this category of metaphor includes expressions like surge, as in "a recent surge of Yemeni refugees entering the island", inflow, as in "the island's lax visa system to be changed and for the inflow of Yemeni refugees to be stopped", pressure, as in "bowing to public pressure against the country's acceptance of refugees", wave, as in "a wave of Yemenis arrived on Jeju Island this year", flow, as in "the government to clamp down on the flow of asylum seekers", tide, as in "hoping to stem the tide of asylum seekers to the island". According to Abid, Manan and Amir (2017, 138), who examined the metaphors used in the representation of Syrian refugees in the host and non-host countries, the water mass metaphor "represents Syrian refugees as an unwelcome disaster as well as detaches any human aspect that Syrian refugees have. This renders them indistinguishable and as dehumanised entities". Furthermore, Gabrielatos and Baker $(2008,31)$ stated that the implementation of water metaphors in representing refugees "gives rise to negative semantic prosodies related to the alleged inordinate number and perceived attendant threat, of refugees".

The most prominent metaphor used in depicting the controversy caused by the existence of Yemeni refugees is the metaphor of spark which is mainly used to represent the division and tension inflicted on the fabric of South Korean society because of Yemeni refugees, for example, "Yemenis has sparked a public dispute in South Korea", "their sudden arrivals have sparked concerns" and "their presence has sparked a public uproar in South Korea". To complement this category of metaphor, the burden metaphor is used to explain the inflicted pressure on South Korea because of the Yemeni refugees, as in "I believe Jeju shouldn't bear the burden of refugees all alone". 
To better enhance the comprehension of the way these metaphors render Yemeni refugees, the concept of topos of definition is fundamental to be integrated. The rule of the topos of definition as described by Wodak $(2001,75)$ is:

If an action, a thing or a person (group of persons) is named/designated (as) X, the action, thing or person (group of persons) carries or should carry the qualities/traits/attributes contained in the (literal) meaning of X.

Consequently, when Yemenis are believed to be "burdening", "sparking" and "surging" the context in which South Korean residents reside, the negative features of these expressions are credited to the Yemeni refugees. This approach is deliberate to entrench fear in the public so that they will likewise see refugees as a hazard to their country (Mayr 2008).

\section{Conclusion}

This study examined the representation of the Yemeni refugees by South Korean media to find out whether the overall paradigm shift of media altered the negative way these groups of people were depicted with. The analysis of Van Leeuwen's (2008) sociological categories of discourse indicated that the general depiction of refugees is negative. This negative representation is divulged from the analysis of role allocation which indicated that Yemeni refugees are activated to depict their entry via relatively neutral verbs (i.e. came and cross) and verbs that depict their massive and incontrollable number (i.e. surge and pour). Yemenis are subjected to mainly criticise their presence in South Korea. The analysis of genericisation and specification indicated that Yemeni refugees are predominantly genericised to eradicate them from the readers' world, thus, deeming them as the distant "others". There are only few instances in the articles whereby Yemeni refugees are specified to humanise them to the readers via giving them voices and emotions. Yemeni refugees are frequently aggregated and collectivised, thus, dehumanising them and deeming them as massive numbers and inanimate entities. Exophoric references deem Yemenis negatively as the main reason for worsening the lives of the locals. The analysis of identification indicated that this linguistic repertoire is used to signal the gender and religion of Yemeni refugees.

The results from Lakoff and Johnsons' conceptual metaphor theory indicated that the main metaphors used in the representation of Yemeni refugees are the water metaphors which symbolise their entry as a natural disaster to South Korea. Furthermore, the media tend to use the metaphor of sparking to depict Yemeni refugees as destroyers of the fabric of South Korea. 
Consequently, the results in this article contradict the hypothesis made by the author because Yemeni refugees are still undesirably represented by the media of South Korea regardless of their small number. This situation demonstrates that the researchers and academicians who worked on this subject did not alter the manner through which minority groups are portrayed by the media of the majority groups. The negative representation of minority groups, Yemeni refugees in this article, is in line with several other studies such as Rojo and Van Dijk (1997), Teo (2000), Baker et al. (2008), Gabrielatos and Baker (2008), KhosraviNik (2009), Cartner (2009), Rasinger (2010), Hanson-Easey and Augoustinos (2010) and Abid, Manan and Amir (2017). The continuance of such undesirable representation of these groups by the media, which is well-known for its influence on the public's frame of thought, endangers their existence in their host countries. It is hoped that the multi-layered analysis of discourse that this research offers will provide awareness to readers about the way blameless Yemenis are rendered negatively in the online media news reports of South Korea in order to resist such partial xenophobic representations. Furthermore, it is fundamental for the media of South Korea to alter their view of Yemeni refugees because such negative portrayals will only deteriorate their already tormented condition.

\section{Appendix}

Sources of the news articles' quotes

\begin{tabular}{lll}
\hline No. Quote & Source \\
\hline 1. $\quad \begin{array}{l}\text { "more than 500 Yemenis have arrived on } \\
\text { Jeju Island this year" }\end{array}$ & $\begin{array}{l}\text { The JoongAng Ilbo. 2018. Yemeni } \\
\text { refugees become a major issue on Jeju, } \\
\text { 20 June. } \\
\text { 2. } \quad \text { "39 Yemeni asylum seekers arrived and } \\
\text { their numbers grew to 92 in 2016" }\end{array}$ & $\begin{array}{l}\text { The Korea Herald. 2018. Yemeni asylum } \\
\text { seekers on Jeju to get results in two } \\
\text { weeks, 11 July. }\end{array}$ \\
3. $\quad$ "over 500 Yemeni refugees arrived on Jeju & $\begin{array}{l}\text { The Korea Times. 2018. Is xenophobia in } \\
\text { Korea's DNA?, 22 July. }\end{array}$ \\
4. $\quad$ "he Yemenis normally flew on a direct & $\begin{array}{l}\text { The JoongAng Ilbo. 2018. Yemeni } \\
\text { refugees become a major issue on Jeju, } \\
\text { flight from Malaysia" }\end{array}$ & $\begin{array}{l}\text { 20 June. } \\
\text { The Korea Times. 2018. South Koreans } \\
\text { stage anti and pro-refugee rallies as } \\
\text { Yemenis arrive, 1 July. }\end{array}$ \\
\hline
\end{tabular}




\section{Appendix (Continued)}

\begin{tabular}{l} 
No. Quote \\
\hline $6 . \quad \begin{array}{l}\text { "more than } 500 \text { Yemeni asylum seekers } \\
\text { arrived in Jeju under a no-visa program" }\end{array}$ \\
7. "the Yemenis have entered Korea on the \\
island's visa-free program" \\
8. "some Yemenis come to us saying they are \\
about to go broke" \\
"some Yemenis in Jeju have resorted \\
to sleeping outside"
\end{tabular}

12. "Yemeni asylum seekers on South Korea's Jeju Island are in need of medical attention"

13. "more than 500 Yemeni refugees are stuck on Jeju Island"

14. "the Yemenis are currently 'stranded' in Jeju"

15. "a total of 552 Yemenis registered for refugee recognition in Korea"

16. "Yemeni refugees are waiting for human rights consultations at the Jeju Migrant Center"

17. "Yemeni asylum seekers wait for their chance to explain their case to human rights officials"

18. "the Yemenis are terrorists in the guise of refugees"

19. "the refugees are dangerous and should not be accommodated"

20. "Yemeni asylum seekers are men"
Source

The Korea Herald. 2018. Koreans hold rallies in support of, and against, asylum seekers, 1 July.

The Korea Times. 2018. Vatican's envoy delivers pontiff's donation to support Yemeni refugees on Jeju, 29 July.

The JoongAng Ilbo. 2018. Asylum seekers are low on cash, 21 July.

The JoongAng Ilbo. 2018. Asylum seekers are low on cash, 21 July.

The Korea Times. 2018. Yemenis find hope and despair in Jeju, 20 June.

The Korea Herald. 2018. Yemeni asylum seekers on Jeju still need medical assistance: Human rights agency, 6 July.

The Korea Herald. 2018. Yemeni asylum seekers on Jeju still need medical assistance: Human rights agency, 6 July.

The Korea Herald. 2018. Dilemma on refugees, 27 June.

The Korea Herald. 2018. Yemeni asylum seekers in Jeju hope to reduce prejudices, 25 June.

The JoongAng Ilbo. 2018. Korea to shorten asylum process, 30 June.

The Korea Times. 2018. Jeju Uprising anniversary can shape response to Yemeni refugees, 2 July.

The Korea Times. 2018. Record number of Koreans sign anti-refugee petition, 6 July.

The Korea Times. 2018. How Jeju became haven for Yemeni refugee, 21 June.

The Korea Times. 2018. Jeju Uprising anniversary can shape response to Yemeni refugees, 2 July.

The JoongAng Ilbo. 2018. Younger Koreans largely oppose refugees, survey shows, 8 August. 


\section{Appendix (Continued)}

\begin{tabular}{|c|c|}
\hline No. & Quote \\
\hline 21. & $\begin{array}{l}\text { "Yemeni asylum seekers in Jeju have } \\
\text { become a controversial issue in South } \\
\text { Korea" }\end{array}$ \\
\hline 22. & "Yemeni refugees has divided the island \\
\hline 23. & $\begin{array}{l}\text { "some Yemeni asylum seekers on Jeju } \\
\text { Island have also begun working for } \\
\text { used-car dealerships" }\end{array}$ \\
\hline
\end{tabular}

24. "the refugees are receiving jobs in industries that do not heavily employ locals"

25. "a group of Yemenis attend a job consulting session on Jeju Island"

26. "Yemeni refugees line up to receive employment assistance at the Jeju Immigration Office"

27. "Yemenis would steal jobs previously held by Koreans"

28. "Yemenis came to Korea for financial reasons"

29. "Koreans are in danger of terrorism because of the Yemenis"

30. "some radicals paint the Yemenis as terrorists in the guise of refugees", "rumours about refugees and Muslims also raised fear among the public"

31. "rumours about refugees and Muslims also raised fear among the public"

32. "some opponents spread 'Islamophobia' and allege the Yemenis are terrorists"

33. "some believe the Yemenis arrived solely for economic advantages"

34. "it takes too much money to house, educate and feed the refugees"

The Korea Herald. 2018. Unprecedented influx of Yemeni asylum seekers in Jeju sparks public discussion on refugees, 25 June.

The Korea Times. 2018. How Jeju became haven for Yemeni refugee, 21 June.

YonHap News. 2018. Pope sends donation to help Yemenis in Jeju, 30 July.

The Korea Times. 2018. Is xenophobia in Korea's DNA?, 22 July.

35. "some are worried Yemenis would steal jobs"

The Korea Times. 2018. How Jeju became haven for Yemeni refugee, 21 June. 


\section{Appendix (Continued)}

\begin{tabular}{ll}
\hline No. & Quote \\
\hline $36 . \quad$ "some see the influx of refugees as a \\
security threat" \\
37. "those who oppose (refugees) say they \\
want safety" \\
38. "allowing Yemeni refugees will inevitably \\
lead to rise in sex crimes" \\
39. "younger women in particular expressed \\
the most concern about refugees" \\
40. "online users also expressed concerns of \\
a rise in sexual or child-related crimes, \\
viewing Yemenis as potential criminals \\
or terrorists" \\
"the romantic streets of Paris fade away \\
thanks to refugees" \\
"we've seen and heard a lot about social \\
problems that occurred in Europe after they \\
took refugees"
\end{tabular}

43. "another notable case was mass sexual assaults against dozens of women by Muslim refugees from North Africa in Cologne, Germany"

44. "a homogenous country divided over how to handle over 500 Yemenis"

45. "South Koreans are divided on the issue of refugees"

46. "the nation is divided over the Yemeni refugees"

47. "Korean churches divided over Yemeni refugees"

48. "a Protestant church pastor expressed worries about the Yemeni refugees"

Source

The JoongAng Ilbo. 2018. Refugee issue prominent at Jeju Forum, 28 June.

YonHap News. 2018. S. Koreans hold rallies in support of, and against, asylum seekers, 30 June.

The Korea Herald. 2018. Anti-refugee sentiment flares up on Cheong Wa Dae petitions, 18 June.

The JoongAng Ilbo. 2018. Younger Koreans largely oppose refugees, survey shows, 7 August.

The Korea Herald. 2018. Unprecedented influx of Yemeni asylum seekers in Jeju sparks public discussion on refugees, 25 June.

The Korea Herald. 2018. Opponents dominate online refugee debate, 4 July.

The Korea Times. 2018. Korean churches divided over Yemeni refugees, 22 June.

The JoongAng Ilbo. 2018. Fake news poisons refugee debate, 2 July.

The JoongAng Ilbo. 2018. Rancor over "fake refugees" continues to divide, 27 July.

The Korea Herald. 2018. Unprecedented influx of Yemeni asylum seekers in Jeju sparks public discussion on refugees, 25 June.

The Korea Times. 2018. Actor Jung Woo-sung criticizes double standard on refugees, 27 June.

The Korea Times. 2018. Korean churches divided over Yemeni refugees, 22 June.

The Korea Times. 2018. Korean churches divided over Yemeni refugees, 22 June. 


\section{Appendix (Continued)}

\begin{tabular}{ll}
\hline No. & Quote \\
\hline 49. & "the Ministry of Justice, in charge of \\
& $\begin{array}{l}\text { refugee policies, will seek for refugees to } \\
\text { settle and find jobs here" }\end{array}$ \\
$50 . \quad$ & "Human Rights Commission of Korea \\
& $\begin{array}{l}\text { lifted a restriction preventing refugees from } \\
\text { getting a job" }\end{array}$
\end{tabular}

51. "the local government has been helping the asylum seekers"

52. "local government plans to provide emergency medical relief for the Yemenis"

53. "the local government would provide humanitarian assistance to the Yemenis"

54. Muneer Almammari, also a former journalist who arrived in Jeju on May 5, said they were grateful for how Korea had legally allowed them to stay and for the people who willingly helped them.

55. "Before I came here from Malaysia, I was informed that I would need money to spend for two to three weeks in Jeju until I receive the visa to go to Seoul," Mohammed Alghaodari, 34, told The Korea Herald.

56. "Hane and Almammari are among the 561 Yemeni asylum seekers"

57. "the recent arrival on Jeju Island of 549 Yemenis fleeing civil war and hunger"

58. "a total of 561 Yemenis arrived on Jeju Island this year"

59. "many Yemeni asylum seekers have registered for refugee"

60. "there are around 800 refugees, but the number is probably much bigger"

61. "most Yemenis arrive via direct flights from Malaysia"

62. "most refugees arrived with little money to live there"
Source

The Korea Times. 2018. Korea will continue to accept refugees, but screening will get tougher, 2 August.

The Korea Times. 2018. Yemeni refugees' fate tested on Jeju Island, 17 June.

The JoongAng Ilbo. 2018. Asylum seekers are low on cash. 21 July.

The Korea Times. 2018. How Jeju became haven for Yemeni refugee, 21 June.

The Korea Times. 2018. How Jeju became haven for Yemeni refugee, 21 June

The Korea Herald. 2018. Unprecedented influx of Yemeni asylum seekers in Jeju sparks public discussion on refugees, 25 June.

The Korea Herald. 2018. Unprecedented influx of Yemeni asylum seekers in Jeju sparks public discussion on refugees, 25 June.

The Korea Herald. 2018. Unprecedented influx of Yemeni asylum seekers in Jeju sparks public discussion on refugees, 25 June.

The Chosun Ilbo. 2018. Over 35,000 refugees seek asylum in Korea, 25 June.

The JoongAng Ilbo. 2018. Asylum seekers are low on cash, 21 July.

The JoongAng Ilbo. 2018. Refugee issue prominent at Jeju forum, 28 June.

The Chosun Ilbo. 2018. Over 35,000 refugees seek asylum in Korea, 25 June.

The JoongAng Ilbo. 2018. Actor brings attention to refugees' plight, 25 June.

The Korea Times. 2018. Yemenis find hope and despair in Jeju, 20 June. 


\section{Appendix (Continued)}

\begin{tabular}{l} 
No. Quote \\
\hline 63. "the number of Yemenis on Jeju swelled \\
by the hundreds", \\
64. "the number of asylum seekers from \\
Yemen on Jeju grew" \\
65. "the number rose more than ten-fold \\
over the past half year" \\
"wanting the government to toughen \\
refugee laws and reject the newcomers" \\
67. "I believe Jeju shouldn't bear the burden \\
all alone" \\
68. "that similar arrivals could follow and their \\
presence could lead to increases \\
in crime"
\end{tabular}

73. "they can stay for up to five years while their case is being assessed"

74. "they are entitled to remain in the country during the court's deliberation"

Source

The JoongAng Ilbo, 2018. Yemeni

refugees become a major issue on Jeju, 20 June.

The JoongAng Ilbo, 2018. Asylum seekers adjusting to Jeju, 26 June.

The Korea Times. 2018. How Jeju became haven for Yemeni refugee, 21 June.

The Korea Times. 2018. Novelist embraces "cultural virus" amid Yemeni refugee dispute, 10 July.

The Korea Times. 2018. Protest planned against Jeju's refugee-friendly policy, 24 June.

YonHap News. 2018. Gov't to speed up refugee screening, 29 June.

The Korea Times. 2018. Voices growing against refugee policy in Korea, 18 June.

The Korea Times. 2018. Korean churches divided over Yemeni refugees, 22 June.

The Korea Times. 2018. Voices growing against refugee policy in Korea, 18 June.

The Korea Times. 2018. Review underway for Yemenis asylum seekers in Jeju, 26 June.

The Chosun Ilbo. 2018. Over 35,000 refugees seek asylum in Korea, 25 June.

The JoongAng Ilbo. 2018. Asylum seekers adjusting to Jeju, 26 June.

75. "they came to Korea to make money"

The JoongAng Ilbo. 2018. Yemeni refugees become a major issue on Jeju, 20 June.

76. "they will take our jobs"

The JoongAng Ilbo. 2018. The lawyers whom asylum seekers call for help, 14 July.

77. "they only came here for jobs"

The JoongAng Ilbo. 2018. The lawyers whom asylum seekers call for help, 14 July. 


\section{Appendix (Continued)}

\begin{tabular}{l} 
No. Quote \\
\hline $78 . \quad$ "they are economic opportunists" \\
79. "they are potential sexual criminals or \\
terrorists" \\
80. "they are Muslims" \\
81. "they may pose security threats" \\
82. "they do not treat women as humans but \\
83. "they were indeed forced to flee their \\
84. "they wanted to avoid getting conscripted \\
85. "they ran out of money to pay for a hotel"
\end{tabular}

86. "they move out to the streets and become homeless"

87. "they are all humans, before anything else"

88. "they fled in search of hope and a better life"

89. "they work either as car dealers or sell second-hand parts scavenged at junkyards"

90. "they could help Jeju ease serious labour shortages in agriculture"

91. "farmers are sympathetic about granting refugee status to the asylum seekers"

92. "other Koreans upset about the Muslims and wanting the government to toughen refugee laws"
Source

The Korea Times. 2018. Is xenophobia in Korea's DNA?, 22 July.

The Korea Herald. 2018. People's anger on social issue directed to asylum seekers: experts, 19 July.

The Korea Herald. 2018. South Korea's "refugee crisis" reveals its gendered Islamophobia, 27 June.

The Korea Times. 2018. Korea will continue to accept refugees, but screening will get tougher, 2 August.

The Korea Herald. 2018. Opponents dominate online refugee debate, 4 July.

The JoongAng Ilbo. 2018. Asylum seekers adjusting to Jeju, 26 June.

The Korea Times. 2018. Is xenophobia in Korea's DNA?, 22 July.

The Korea Herald. 2018. Unprecedented influx of Yemeni asylum seekers in Jeju sparks public discussion on refugees, 25 June.

The Korea Times. 2018. Yemenis find hope and despair in Jeju, 20 June.

The Korea Herald. 2018. Romanian nun helps Jeju's Yemeni asylum seekers, migrant families, 13 July.

The Korea Times. 2018. Actor Jung Woo-sung criticizes double standard on refugees, 27 June.

The Chosun Ilbo. 2018. Used-car market draws Syrians to Korea, 4 July.

The Korea Times. 2018. How Jeju became haven for Yemeni refugee, 21 June.

The Korea Times. 2018. How Jeju became haven for Yemeni refugee, 21 June.

The Korea Times. 2018. Novelist embraces "cultural virus" amid Yemeni refugee dispute, 10 July. 
Appendix (Continued)

\begin{tabular}{ll}
\hline No. & Quote \\
\hline 93. & "they are Muslims" \\
94. $\quad \begin{array}{l}\text { a common argument goes that Muslim } \\
\text { refugees will not assimilate into the larger } \\
\text { mainstream society" }\end{array}$ \\
95. $\quad \begin{array}{l}\text { rumours about refugees and Muslims also } \\
\text { raised fear among the public" }\end{array}$
\end{tabular}

96. "a Korean man claimed that Muslim men only see women as the "subject of rape and murder"”

97. "some raised issues over possible repercussions that a large influx of mostlymale foreigners from a different cultural background may have on the Korean society"

98. "he (a South Korean) claimed that by allowing male refugees from Yemen, many of whom are single, to stay on Jeju, the Korean government is 'putting Korea's young women in danger'”

99. "unprecedented influx of Yemeni asylum seekers in Jeju sparks public discussion"

100. “Jeju Island saw an influx of asylum seekers from Yemen"

101. "the unprecedented influx of Yemeni asylum seekers in Jeju has become a controversial issue"

102. "a recent surge of Yemeni refugees entering the island"

103. "the island's lax visa system to be changed and for the inflow of Yemeni refugees to be stopped"

The Korea Herald. 2018. South Korea's "refugee crisis" reveals its gendered Islamophobia, 27 June.

The Korea Herald. 2018. Unprecedented influx of Yemeni asylum seekers in Jeju sparks public discussion on refugees, 25 June.

The JoongAng Ilbo. 2018. 7 Yemenis get exception to leave Jeju for the mainland, 17 July.

The Korea Herald. 2018. Unprecedented influx of Yemeni asylum seekers in Jeju sparks public discussion on refugees, 25 June.

The Korea Times. 2018. How Jeju became haven for Yemeni refugee, 21 June.

The Korea Times. 2018. Yemeni refugees' fate tested on Jeju Island, 17 June. 


\section{Appendix (Continued)}

\begin{tabular}{|c|c|c|}
\hline No. & Quote & Source \\
\hline 104. & $\begin{array}{l}\text { "bowing to public pressure against the } \\
\text { country's acceptance of refugees" }\end{array}$ & $\begin{array}{l}\text { The JoongAng Ilbo. 2018. } 7 \text { Yemenis get } \\
\text { exception to leave Jeju for the mainland, } \\
17 \text { July. }\end{array}$ \\
\hline 105. & $\begin{array}{l}\text { "a wave of Yemenis arrived on Jeju Island } \\
\text { this year" }\end{array}$ & $\begin{array}{l}\text { The JoongAng Ilbo. } 2018 \text {. Korea to } \\
\text { shorten asylum process, } 30 \text { June. }\end{array}$ \\
\hline 106. & $\begin{array}{l}\text { "the government to clamp down on the } \\
\text { flow of asylum seekers" }\end{array}$ & $\begin{array}{l}\text { The JoongAng Ilbo. 2018. Asylum seekers } \\
\text { are low on cash, } 21 \text { July. }\end{array}$ \\
\hline 107. & $\begin{array}{l}\text { "hoping to stem the tide of asylum seekers } \\
\text { to the island" }\end{array}$ & $\begin{array}{l}\text { The JoongAng Ilbo. } 2018 \text {. Actor brings } \\
\text { attention to refugees' plight, } 25 \text { June. }\end{array}$ \\
\hline 108. & $\begin{array}{l}\text { "Yemenis has sparked a public dispute in } \\
\text { South Korea" }\end{array}$ & $\begin{array}{l}\text { The Korea Herald. 2018. Unprecedented } \\
\text { influx of Yemeni asylum seekers in Jeju } \\
\text { sparks public discussion on refugees, } \\
25 \text { June. }\end{array}$ \\
\hline 109. & $\begin{array}{l}\text { "their sudden arrivals have sparked } \\
\text { concerns" }\end{array}$ & $\begin{array}{l}\text { The Korea Times. 2018. Vatican's envoy } \\
\text { delivers pontiff's donation to support } \\
\text { Yemeni refugees on Jeju, } 29 \text { July. }\end{array}$ \\
\hline 110. & $\begin{array}{l}\text { "their presence has sparked a public uproar } \\
\text { in South Korea" }\end{array}$ & $\begin{array}{l}\text { The Korea Herald. } 2018 \text {. Yemeni } \\
\text { asylum seekers on Jeju still need medical } \\
\text { assistance: Human rights agency, } 6 \text { July. }\end{array}$ \\
\hline 111. & $\begin{array}{l}\text { "I believe Jeju shouldn't bear the burden of } \\
\text { refugees all alone" }\end{array}$ & $\begin{array}{l}\text { The Korea Times. 2018. Protest planned } \\
\text { against Jeju's refugee-friendly policy, } \\
24 \text { June. }\end{array}$ \\
\hline
\end{tabular}

\section{References}

Abid, R.Z., Manan, S.A. and Amir, Z.A. 2017. A flood of Syrians has slowed to a trickle: The use of metaphors in the representation of Syrian refugees in the online media news reports of host and non-host countries. Discourse and Communication 11(2): 121-140. https://doi.org/10.1177/1750481317691857

Baker, P., Gabrielatos, C., KhosraviNik, M., Krzyzanowski, M., McEnery, T. and Wodak, R. 2008. A useful methodological synergy? Combining critical discourse analysis and corpus linguistics to examine discourses of refugees and asylum seekers in the UK press. Discourse and Society 19(3): 273-306. https://doi. org/10.1177/0957926508088962

Baroni, M. and Bernardini, S. 2004. BootCaT: Bootstrapping corpora and terms from the web. In LREC 2004 fourth international conference on language resources and evaluation, eds. M.T. Lino, M.F. Xavier, F. Ferreira, R. Costa and R. Silva, 13131316. Paris: Evaluations and Language resources Distribution Agency (ELDA). http://www.lrec-conf.org/proceedings/lrec2004/pdf/509.pdf (Accessed 30 June 2018). 
Cartner, J.M. 2009. Representing the refugee: Rhetoric, discourse and the public agenda. MA dissertation, University of Notre Dame Australia, Fremantle.

Gabrielatos, C. and Baker, P. 2008. Fleeing, sneaking, flooding: A corpus analysis of discursive constructions of refugees and asylum seekers in the UK press, 1996-2005. Journal of English Linguistics 36(1): 5-38. https://doi.org/10.1177/ 0075424207311247

Ghani, F. 2018. Yemeni refugee on escaping war and life on South Korea's Jeju. Al Jazeera, 18 August. https://www.aljazeera.com/indepth/features/yemeni-refugee -escaping-war-life-south-korea-jeju-180816071438268.html

Hanson-Easey, S. and Augoustinos, M. 2010. Out of Africa: Accounting for refugee policy and the language of causal attribution. Discourse and Society 21(3): 295-323. https://doi.org/10.1177/0957926509360744

KhosraviNik, M. 2009. The representation of refugees, asylum seekers and immigrants in British newspapers during the Balkan Conflict (1999) and the British General Election (2005). Discourse and Society 20(4): 477-498. https://doi.org/10.1177/ 0957926509104024

Kövecses, Z. 2010. Metaphor. Oxford: Oxford University Press, Inc.

Lakoff, G. 2004. Don't think of an elephant! Know your values and frame the debate: The essential guide for progressives. Vermont, USA: Chelsea Green Publishing Company.

1991. Metaphor and war: The metaphor system used to justify war in the Gulf. Peace Research 23(2/3): 25-32.

Lakoff, G. and Johnson, M. 2003. Metaphors we live by. London: The University of Chicago Press.

Mayr, A. 2008. Language and power: An introduction to institutional discourse. London: Continuum International Publishing Group.

Papathanassopoulos, S., ed. 2011. Media perspectives for the 21st century. London: Routledge.

Park, S.N. 2018. South Korea is going crazy over a handful of refugees. Foreign Policy, 11 August. https://foreignpolicy.com/2018/08/06/south-korea-is-going-crazy-over -a-handful-of-refugees/

Rasinger, S.M. 2010. Lithuanian migrants send crime rocketing: Representation of "new" migrants in regional print media. Media Culture Society 32(6): 1021-1030. https://doi.org/10.1177/0163443710380311

Rojo, L.M. and Van Dijk, T.A. 1997. “There was a problem and it was solved!”: Legitimating the expulsion of "illegal" migrants in Spanish parliamentary discourse. Discourse and Society 8(4): 523-566. https://doi.org/10.1177/0957926597008004005

Santoro, C. 2012. Asylum seekers, refugees and media. Information Centre about Asylum Seekers and Refugees (ICAR) briefing. London: ICAR. http://www.icar.org.uk/ Asylum_Seekers_and_Media_Briefing_ICAR.pdf (accessed 24 March 2013).

Talbot, M. 2007. Media discourse: Representation and interaction. Edinburgh, UK: Edinburgh University Press Ltd.

Tator, C., Henry, F. and Mattis, W. 1998. Challenging racism in the arts: Case studies of controversy and conflict. Toronto: The University of Toronto Press. 
Teo, P. 2000. Racism in the news: A critical discourse analysis of news reporting in two Australian newspapers. Discourse and Society 11(1): 7-49. https://doi. org/10.1177/0957926500011001002

Törnberg, A. and Törnberg, P. 2016. Muslims in social media discourse: Combining topic modeling and critical discourse analysis. Discourse, Context and Media 13: 132142. https://doi.org/10.1016/j.dcm.2016.04.003

United Nations High Commissioner for Refugees (UNHCR). (n.d.) Who is a refugee? http://www.unrefugees.org/site/c.lfIQKSOwFqG/b.4950731/ (accessed 23 April 2013).

Van Leeuwen, T. 2008. Discourse and practice. New York: Oxford University Press.

Wodak, R. 2001. The discourse-historical approach. In Methods of critical discourse analysis, eds. R. Wodak and M. Meyer, 63-93. London: SAGE Publications Ltd. 